ISSN: 2224-0616

Int. J . Agril. Res. Innov. \& Tech. 4 (2): 29-34, December, 2014 Available online at http:// www.ijarit.webs.com

\title{
INSTITUTIONAL PROVISIONS FOR ADMINISTRATION OF RURAL DEVELOPMENT PROGRAMMES: EXPERIENCE FROM FADAMA 111 DEVELOPMENT PROGRAMME IN TARABA STATE, NIGERIA
}

\author{
M.U. Dimelu1,2*, F.H. Bonjoru1, A.I. Emodi1 and M.C. Madukwe2 \\ Received 6 June 2014, Revised 8 November 2014, Accepted 22 December 2014, Published online 31 December 2014
}

\begin{abstract}
The study examined institutional provisions in the implementation of Fadama 111 Development Project in Taraba State, Nigeria during 2008-2013. All the staff of the project (57) from eight out of 16 local government areas participated in the programme was used in the study. Data were collected with questionnaire and analysed using descriptive statistics. The results showed strong linkages of the state Fadama coordinating office with government parastaltals and organizations at different levels of the project implementation. There were strong adherence to rules and regulations guiding staff recruitment, financial management, preparation of local development plan, environmental compliance and friendliness, and group formation. The project was constrained by several institutional factors namely delay in the payment of counterpart fund by the government $(\mathrm{M}=3.39)$, lack of transport and other logistic supports $(\mathrm{M}=3.06)$, lack of payment of counterpart fund by the government $(\mathrm{M}=3.04)$ and others. The study recommends that policy makers and development planner should ensure functional mechanisms that could foster and enhance linkages, and support adherence to rules and regulations prescribed for implementation of development programmes.
\end{abstract}

Keywords: Fadama Project, Fadama User Group, Fadama Community Association, Linkage, Institution

${ }^{1}$ Department of Agricultural Extension, University of Nigeria Nsukka, Nigeria

${ }^{2}$ Department of Agricultural Extension and Economics, River State University, Port Harcout, Nigeria

*Corresponding author's email: mabeldimelu@yahoo.com (M.U. Dimelu)

\section{Introduction}

The National Fadama Development Programme (NFDP) was incepted following success stories from small-scale irrigation projects carried out by the Agricultural Development Programmes (ADPs) in Fadama areas. Fadama is a Hausa word, meaning flood plains. According to Akinola (2003), the first phase of Fadama Development Programme (Fadama I) was implemented between 1992 and 1998 and it promoted production of arable crops in Fadama areas. The project adopted the small-scale irrigated farming system (SSIFS), as the preferred option because of its cost saving features when compared with large-scale irrigation projects in Nigeria. It was designed with the major aim of harnessing the substantial surface and underground water resources for small-scale irrigated agriculture through private sector participation. Following the successes recorded in Fadama I Project, the second phase of NFDP (Fadama II) was declared loan disbursement effective on the 27th May, 2004 with the actual disbursement to beneficiaries in September 2005. Unlike Fadama I, which covered the cultivation of only few arable crops, Fadama II Project emphasized both farm and non-farm activities linked to Fadama resources, as well as conflict resolution among fadama resource users. Its development objective was to sustainably increase the incomes of all Fadama resource users (those who depend directly or indirectly on Fadama resources) (FMA and WR, 2008). Fadama II concentrated on a number of agricultural areas termed components. These components include rural infrastructure investments, pilot asset acquisition, demand driven advisory services and improved mechanisms to avoid and manage conflicts among Fadama resource users.

The successes recorded in both phases of the project informed the implementation of the third phase (Fadama-III) with addition of more components and sub components. For instance, rural finance/livelihood, public ADP and adaptive research support component were introduced with specialists in rural development and other supportive staff to handle credit issues for the Fadama III beneficiaries. Furthermore, sub components such as sustainable land management (SLM), the Fadama user equity fund (FUEF) were established from which beneficiaries borrow money at a reduced interest 
rate to finance the purchase of productive assets. Thus, effective implementation of the project demands adequate institutional provisions and arrangements.

The institutional mechanisms/design provides essential links, collaborations and roles for all the components and organizations involve in the implementation processes. Under Fadama III, the institutional arrangement from the federal level to the local government level is expected to be well defined. At each level, components and organizations are to explore the linkages for effective execution of roles and complementarities in functions in the system. In addition, rules and regulations guiding every operation should be clearly stated. These rules may include those on sub-project design and preparation; environmental compliance and friendliness; financial management; group formation; preparation of local development plan, staff recruitment and so on.

Kanshahu (2000) asserts that for a project to be successfully implemented and have a sustained impact on the lives of the beneficiaries, it must be well managed. He stresses that good management is facilitated by adequate institutions, that is, by supportive organizations, laws, policies, procedures and rules. In other words, inadequate and disregard for institutional provisions can undermine the effectiveness of any rural development project. Therefore, the study aimed to examine the institutional provisions in the implementation of Fadama 111 Development Project. It ascertains the extent of adherence to the rules and regulations guiding the implementation of the project and identifies perceived institutional issues that constrained effective implementation of Fadama III project in the state.

\section{Methodology}

The study was carried out in Taraba State of Nigeria. Taraba State lies approximately between latitude $6030^{11}$ and 903611 north and longitude $9^{010^{11}}$ and $11^{050} 0^{11}$ east and covers a land mass of 60,291.82 km² (Taraba State Official Diary, 2012). As a result of its agrarian nature, a good proportion of the population is engaged in farming as occupation. About three quarters (75\%) of the people are crop farmers, livestock farmers and fish farmers while an estimated one quarter $(25 \%)$ are engaged in other economic activities (Taraba Agricultural Development Programme (TADP, 1998).

The population comprised the management staff as well as other personnel employed at the state and local government offices of Fadama III Project in the state. There are sixteen local government areas (LGAs) in Taraba State and all of them participated in Fadama III Project. Fifty per cent of the LGAs were selected through simple random sampling technique giving eight LGAs. All the management staff (9) at the State Fadama Coordinating Office, the 32 facilitators in the selected LGAs and the sixteen desk officers at the Local Fadama Desks Office was used giving 57 respondents for the study. The data were collected through use of questionnaire and secondary data from official documents.

The respondents were asked to indicate organizations that are linked to the implementation processes of the program and the strength of the linkages. (e.g linkage between the Fadama III staff in the state coordinating office and actors in federal government ministries/parastatals, donor agencies, state government ministries/parastatals, local governments, service providers etc). This was achieved using four point Likert-type scale of strong $=4$, moderate $=3$, weak $=2$ and no linkages $=1$. These values were added and divided by 4 to get the mean value of 2.5. Any value $\geq 2.50$ was regarded as strong linkage while value $<2.50$ represented weak linkage.

The rules and regulations guiding the operation of Fadama III in areas of project management and preparation, staff recruitment, financial management, preparation of local development plans, environment compliance and friendliness and group formation were assessed. The respondents were asked to indicate the degree of adherence to these rules and regulations on 5point Likert-type scale of very strong (5), strong (4), moderatel (3), weak (2), very weak (1). These values were added and divided by 5 to get a cutoff point of 3.0. Any value $\geq 3.0$ meant strong adherence while value of $<3.0$ was considered weak adherence to the rules and regulations. Also information on the perceived institutional constraints (example lack of payment of counterpart fund by the government, delay in the payment of counterpart fund, late disbursement of funds by the Fadama office, bureaucratic bottlenecks) to the project was elicited from the respondents using 4-point Likert- type scale of very serious (4), serious (3), less serious (2) and not serious (1). The nominal values were added and divided by 4 to get a mean value of 2.50 . Constraint items with mean scores $\geq 2.50$ were considered as serious, while $<2.50$ was regarded as not a serious constraint.

\section{Results and Discussion Linkages of SFCO with parastatals and organizations}

The level of linkages between the personnel of state Fadama coordinating office (SFCO) and other actors of Fadama III was discussed under the following headings: 
State fadama coordinating office linkage/collaboration with federal ministries and parastatals

The SFCO had strong linkages with Federal Ministry of Agriculture and Water Resources $(\mathrm{M}=3.37)$, Federal Ministry of Environment and Federal Ministry of Finance (M=3.27), National Food Reserve Agency $(\mathrm{M}=3.25)$, and Federal Ministry of Education ( $M=2.58)$. However, the standard deviation shows wide variance in the respondents' opinion of the strength of the linkages. Relatively, the results suggest some level of partnership and cooperation between the staff of SFCO and those of the federal ministries and parastatals. Structurally, the project is designed such that relevant institutions partner at different implementation stage, field and around Fadama resources. Hence, the need for interaction, exchange and flow of information, among the manpower and institutional elements in all the different collaborating ministries and agencies that are directly or indirectly involve in implementing the project. Where this is lacking it could undermine efforts in the implementation process. For instance, linkage according to Ani (2007) is very necessary among researchers, extension practitioners, farmers and policy makers because it enables each category of the actors to wake up to the realization that solution to problems related to linking knowledge generations, dissemination and utilization requires a system's approach. Linkages between the SFCO and the collaborating ministries/agencies ensure productive communication, efficient resource use and enhanced performance of the entire project implementation process.

Table 1. Mean score distribution on linkage between the staff of SFCO and other actors in Fadama III Project

\begin{tabular}{lcc}
\hline Federal parastatals & Mean (M) & Standard deviation (SD) \\
\hline Federal Ministry of Agric and Water Resources & 3.37 & 0.850 \\
National Food Reserve Agency & 3.25 & 0.857 \\
Federal Ministry of Environment & 3.27 & 0.962 \\
Federal Ministry of Finance & 3.27 & 1.112 \\
Federal Ministry of Education & 2.58 & 1.270 \\
\hline State ministries/ agencies & & \\
\hline State Ministry of Agric (SMA) & 3.66 & 0.769 \\
State Ministry of Finance/ & 3.61 & 0.803 \\
State Ministry of Education & 2.52 & 1.338 \\
State Ministry of Women Affairs & 2.69 & 1.168 \\
State of Ministry Environment & 3.07 & 1.016 \\
\hline Service providers & & \\
\hline ADPS & 3.39 & 0.941 \\
National Livestock Development Programmes & 3.07 & 1.215 \\
ARMTI & 2.79 & 1.114 \\
Universities & 2.85 & 1.156 \\
IITA & 3.05 & 1.117 \\
Individual consultants & 3.19 & 0.981 \\
Private entrepreneurs & 3.00 & 1.000 \\
Community groups & 3.30 & 0.912 \\
NGOs & 3.19 & 1.111 \\
Qualified Civil Organizations & 3.07 & 1.035 \\
\hline Community level fadama organizations & & \\
\hline Local Fadama Community Desks & 3.55 & 0.910 \\
FCAs/ FUGs & 3.39 & 0.780 \\
\hline
\end{tabular}

State fadama coordinating office (SFCO) linkages with state ministries and parastatals

The state Fadama coordinating office are strongly linked to the State Ministry of Agriculture and Natural Resources $(M=3.66)$, State Ministry of Finance (M=3.61), State Ministry of Environment $(M=3.07)$, State Ministry of Women affairs $(\mathrm{M}=2.69)$, and State Ministry of Education $(\mathrm{M}=2.52)$ (Table 1). The SFCO carries out day to day coordination, and using resources from the line ministries approves engineering and other consultant services, reviews, screens, and provides clearance on the technical viability of all subprojects submitted for project funding. Besides, most of these organizations are involved in providing services in crop protection, horticulture, agro forestry, credit and environmental management, hence the need for strong linkage. This will boosts efficient resource use, and enhanced performance of the whole development project. 


\section{SFCO linkage with service providers}

Table 1 shows that SFCO's had strong link with the ADP $(\mathrm{M}=3.39)$, community groups other than FUGs (M=3.30), individual consultants/privates $(\mathrm{M}=3.19)$, civil organizations/NGOs $(\mathrm{M}=3.1)$, National Livestock Development Programme $(\mathrm{M}=3.05)$, private entrepreneurs $(\mathrm{M}=3.00)$, universities $(\mathrm{M}=2.85)$, and ARMTI $(\mathrm{M}=2.79)$ (Table 1). This is not surprising because under Fadama III project, increased attention was placed on providing adequate training for the facilitators and Fadama community associations. In addition, much effort was placed on the involvement of civil society (e.g., NGOs and other community-level professional associations/service providers); particularly with respect to information, mobilizing the vulnerable groups, and supporting training activities at the community level (World Bank, 2008). These organizations played one or two of the above roles. Consequently, strong linkage with the organizations is apt to ensure adequate training of facilitators and subsequent provision of technical advice, efficient service delivery, community empowerment and improved quality of decision-making within FCAs. Many rural development interventions have failed because of neglect of interdependency in roles, particularly in integrated development approach.

SFCO linkage with Fadama Community Associations (FCAs)

Table 2. Mean score on level of adherence to rules and regulations in Fadama 111 Project

\begin{tabular}{lcc}
\hline Rules & (M) & (SD) \\
\hline Rules on project management preparation & 3.77 & 1.460 \\
Approval and periodicals review of work plan and budget & 3.63 & 1.191 \\
Compliance with sector policies during implementation & 1.163 \\
$\begin{array}{l}\text { Approval of annual physical and financial reports, auditor's report and } \\
\text { project accounts }\end{array}$ & 4.05 & \\
Selection of contractors and award of contracts & 3.92 & 1.392 \\
Rules on staff recruitment & 3.82 & 1.468 \\
Requirement on basic minimum qualifications & 3.72 & 1.273 \\
Requirement on post qualifications experience & 1.331 \\
Requirement on experience in a Community Driven Development & 3.56 & \\
project & 3.30 & 1.231 \\
Requirement on relevant skills and computer literacy & 1.454 \\
Requirement on adequate number of both technical and supportive & 3.50 \\
staff & & \\
Rules on financial management & & \\
Following due process in the approval and disbursement of funds & 3.87 & 1.454 \\
Deposit of 30\% up front by the beneficiaries & 4.08 & 1.075 \\
Contribution of 70\% by the project & 4.08 & 1.217 \\
Establishment of saving scheme by the FUGs & 3.90 & 1.209 \\
Release of counterpart funds on timely basis by the state government & 3.05 & 1.413 \\
Rules on preparation of Local Development Plans (LDPS) & & \\
Identification of problems & 3.85 & 1.182 \\
Causes of problems & 3.69 & 1.280 \\
Proffering solutions/ actions to be taken & 3.66 & 1.236 \\
Determining implementation period & 3.59 & 1.322 \\
Identifying resources for implementation & 3.88 & 1.289 \\
\hline
\end{tabular}

Int. J . Agril. Res. Innov. \& Tech. 4 (2): 29-34, December, 2014 $(\mathrm{M}=3.59)$ and the staff of the Local Fadama Desk $(M=3.55)$ had strong linkage with staff at SFCO (Table 1). Fadama community associations are apex organizations of economic interest groups (EIGs) which have a common interest; to derive their livelihood from the shared natural resources of Fadama. They identify, prepare, execute, supervise, operate, and maintain their subprojects (Nkonya et al., 2010). They are the direct beneficiaries of Fadama Project. The coordination function of the SFCO is not efficient without strong and functional grass root linkage. Strong linkage between staff of SFCO and the Fadama farmers' organizations at the community level guarantee adequate supervision and successful implementation of the project. Above all, strong linkage between the staff of the SFCO and the fadama organizations ensures cooperation, effective tracking and feedback on the project.

Adherence to rules and regulations in Fadama III Project

The project had clearly stated rules and regulations for the implementation process The staff adhered to all the rules regarding project management and preparation, staff recruitment requirement, financial management, preparation of local development plan, environmental compliance and screening and group formation (Table $2 \& 3$ ). 
Table 3. Mean distribution of respondents based on adherence to rules on environmental compliance and group formation

\begin{tabular}{|c|c|c|}
\hline Rules and regulations & $\begin{array}{l}\text { Mean } \\
(\mathrm{M})\end{array}$ & $\begin{array}{c}\text { Standard } \\
\text { deviation (SD) }\end{array}$ \\
\hline Rules on environmental compliance and friendliness & & \\
\hline $\begin{array}{l}\text { Rules on land clearing and cultivation e.g. bush should not be set on } \\
\text { fire, forest should not be destroyed etc. }\end{array}$ & 3.60 & 1.288 \\
\hline $\begin{array}{l}\text { Rules on irrigation practices e.g. the project should not cause the loss } \\
\text { of available surface water etc. }\end{array}$ & 3.59 & 1.438 \\
\hline Rules on the use of agro-chemicals e.g. observing the rules on & 3.73 & 1.329 \\
\hline $\begin{array}{l}\text { nternational pest management practices etc. } \\
\text { Rules on protecting beneficial animals and insects e.g. the project } \\
\text { should not cause reduction on the number of species or reduce their } \\
\text { habitat }\end{array}$ & 3.59 & 1.328 \\
\hline Rules on fishing practices e.g. avoiding chemicals to kill fish in water & 3.82 & 1.167 \\
\hline $\begin{array}{l}\text { Rules on access roads and tracks construction e.g. road construction } \\
\text { should not destroy animal habitat etc. } \\
\text { Rules on Group Formation }\end{array}$ & 3.68 & 1.430 \\
\hline Disabled persons (blind, deaf, dumb, cripples etc.) & 4.05 & 1.158 \\
\hline Widows & 3.81 & 1.330 \\
\hline The poor & 3.79 & 1.301 \\
\hline Youths & 3.74 & 1.245 \\
\hline Religious groups & 3.38 & 1.426 \\
\hline Women & 3.38 & 1.362 \\
\hline
\end{tabular}

This is contrary to The World Bank appraisal report of Fadama II, which indicated low performance of existing manpower and inadequate adherence to institutional provisions (World Bank, 2008). Particularly, there was low performance in the preparation of local development plans by the officials of the FUGs/FCAs. Also disregard for laid down rules and regulations as cases of collusion between the facilitators and the service providers were reported (IFPRI, 2007). Generally, the results suggest that the project execution was carried out according to World Bank specification. This could be explained by many factors including the monitoring evaluation strategies employed, phases of the project; which together ensures rule compliance, enforcement, conformity to rules guarding implementation and minimizes the abuse and mismanagement of resources (Ghate and Nagendra, 2005). According to Tyler (2005), securing employee adherence to work place rules and company policies is one key antecedent of a successful coordination and functioning within organizations. This is quite very uncommon with most government agricultural programmes due to problems of corruption, administrative bottleneck and bureaucracy and similar man-made problems in public system. Adherence to rules and laws greatly account for the success or failure recorded incorporation of lessons learnt from previous

Perceived Institutional factors affecting theimplementation of Fadama III Project

Table 4. Mean score distribution of institutional factors affecting the implementation of Fadama III project

\begin{tabular}{lcc}
\hline Factors & Mean (M) & Standard Deviation \\
\hline Lack of payment of counterpart fund by the & $3.04^{*}$ & 0.980 \\
government & $3.39^{*}$ & 0.790 \\
Delay in the payment of counterpart fund & $2.98^{*}$ & 1.083 \\
Late disbursement of fund by the fadama office & $2.75^{*}$ & 1.072 \\
Bureaucratic bottlenecks & 1.90 & 1.015 \\
Embezzlement of funds & $3.06^{*}$ & 0.886 \\
Lack of transport and other logistic support & 2.37 & 1.248 \\
Insufficient office facilities (computers, furniture etc) & $2.56^{*}$ & 1.037 \\
Shortage of funds & 2.00 & 1.066 \\
Superstitious beliefs of project beneficiaries & 1.83 & 1.080 \\
Religious prohibition of the acceptance of some sub & & 1.054 \\
projects & 1.71 & 1.093 \\
Lack of taboos & & \\
subprojects & & 1.153 \\
Lack of capacity to enforce rules and regulations & 2.35 & 1.167 \\
Political differences & 2.14 & 1.083 \\
Bad leadership & & \\
\hline
\end{tabular}

*Serious constraints factor

Int. J . Agril. Res. Innov. \& Tech. 4 (2): 29-34, December, 2014 
Table 4 shows that six out of the fifteen items were perceived by the Fadama staff as serious institutional constraints militating against the implementation of the project. These include delay in the payment of counterpart fund by the government $(\mathrm{M}=3.39)$, lack of transport and other logistic support $(\mathrm{M}=3.06)$, lack of payment of counterpart fund by the government $(M=3.04)$, late disbursement of funds by the Fadama III office (M=2.98), bureaucratic bottlenecks $(\mathrm{M}=2.75)$ and shortage of funds $(\mathrm{M}=2.56)$ (Table 1). The findings reveals that most constraints affecting Fadama III project revolve around the way financial issues were handled by the government as well as the Fadama III project itself. In addition to several other criteria, the participation of states in the progamme was based on regular payment of counterpart fund, but as common with government interventions/ programme, poor funding remains a formidable challenge. This confirms the finding of Agwu and Abah (2009) who observe poor funding and late disbursement of funds as problem in the second National Fadama Development Project. Timely and regular release of fund is expedient for financing and implementing main components and subcomponents of project designed to transfer financial and technical resources to the beneficiary groups. Also, the problem of bureaucratic bottleneck is a reoccurring impediment in the execution of government programmes. It delays and forestalls timely implementation of activities of all the components of the project, leading to inefficiency and poor performance of the technical and administrative arrangements.

\section{Conclusion}

Institutional provisions are crucial for effective implementation of development programmes. Fadama 111 Development Project maintained strong linkages with relevant organizations, institutions and associations in the implementation and achievement of the project objectives. The staff strongly adhered to the rules and regulations guiding operation of different components of the project such as project management preparation, staff recruitment, financial management, preparation of Local Development Plans (LDPS) and others. However, the project is constrained by poor funding and bureaucratic bottleneck. In other words, the project had functional institutional arrangements for successful implementation and enhanced performance but lacked adequate funding to facilitate the whole process. Consequently, recording expected impact on the beneficiaries' income, livelihood and poverty level may be a mirage. The study therefore recommends government support through timely payment of counterpart fund and provision of logistic support to facilitate the entire implementation process. Policy makers and development planner should ensure functional mechanisms that could enhance and foster linkages; and promote adherence to rules and regulations prescribed for implementation of development programmes.

\section{References}

Agwu, A.E. and Abah, H.O. 2009. Attitude of farmers towards cost sharing in the second National Fadama Development Project: the case of Kogi State of Nigeria. J . Agril. Ext. 13 (2): 92-106.

Akinola, M.O. 2003. The performance of Fadama users association under the National Fadama Development Project phase One, Nigeria. PhD Thesis, Ahmadu Bello Univerty, Zaria. 73p.

Ani, A.O. 2007 Agricultural Extension: A Pathway for Sustainable Agricultural Development. Apani Publications, Kaduna, Nigeria.

FMA and WR. 2008. Third National Fadama Development Project (fadama III). Project Implementation Manuals. Federal Ministry of Agriculture and Water Resources.

Ghate, R. and Nagendrra, H. 2005. Role of monitoring in institutional performance. Forest management in Maharashtra, India. http:// conservationandsociety.org/ article.as p/ISSN 0972-4923. accessed 2nd August, 2010.

IFPRI. 2007. Beneficiary assessment/impact evaluation of Fadama II Project. A World Bank document on the third National Fadama Development Project (Fadama III). International Food Policy Research Institute. pp. 61-64.

Kanshahu, A.I. 2000. Planning and implementing sustainable projects in developing countries-Theory, practices and economics. $2^{\text {nd }}$ revised and expanded edition. Singapore, AgBe publishing. p. 209.

Nkonya, E.H., Markel Ova, Kato, E., Alomolaron, A., Shetima, A.G., Ingawa, S., Madukwe, M.C., Olukosi, J., Phillip, D. and Park, D. 2010. Baseline Report of Fadama III Impact Assessment Study. International Food Policy Research Institute, Washington, DC, USA. pp. viii.

TADP. 1998. The adoption of technologies under the National Fadama Development Project in Taraba State. Report Prepared for planning, monitory and evaluation subprogramme of Taraba State Agricultural Development Programme.

Taraba State Official Diary. 2012. Official Diary of Taraba State government of Nigeria.

Tyler, T.R. 2005. Promoting employee policy adherence and role following work settings: the value of self regulatory approaches http/www.digitalcommonslaw.yale.edu/cgi/ viewcontent.cgi, accessed $20^{\text {th }}$ October, 2012.

World Bank. 2008. Project appraisal document on a proposed credit to the Federal Republic of Nigeria for third National Fadama Development (Fadama III) Project. p. 52. 